\title{
Public Distrust and Environmental Citizenship: Primary Impetuses of Radical Protest in Bima District, 2011-2012
}

\author{
Rahmad Hidayat \\ Department of Administrative Science of STISIP Mbojo Bima \\ (email: rahidsmart@gmail.com)
}

\begin{abstract}
This article aims to show how the social movement was conducted in the framework of claiming a number of aspects of citizenship, especially environmental rights and political participation, to the local government. The refusal of FRAT Bima over the extractive policy of the Government of Bima District during 2011-2012 becomes a reflective context of the type of social movement with such a framework. This social protest should be explored further because it used acts of vandalism on some public facilities as the chosen way to fight against the environmental and political injustices. Through a case study, the author aims to explore the sequence of repertoires which were applied sequentially by FRAT Bima's social protest as well as to examine its linkage with environmental citizenship and public distrust. Despite being closely related to citizens' awareness about environmental citizenship, the occurrence of this anarchist movement was also triggered by the low level of "formal legitimacy" of the local government as a seed of public distrust towards the intentions of environmental governance policy that was about to be applied to make the agricultural land owned by villagers as the site of a certain project of mineral extraction. The lack of the government's formal legitimacy, which was supported by the growing awareness of environmental citizenship, has led the sequential application of conventional and non-conventional strategies in the demands articulation of FRAT Bima. This sequence of repertoires was held due to the low-level of government's responsiveness in accommodating the public claims about the cancellation of an undemocratic environmental policy.
\end{abstract}

\section{Keywords:}

citizenship; distrust; protest; repertoires; social movement

\section{Introduction}

Burning the Office of Lambu SubDistrict Head (February 10, 2011), Forcefully Occupying the Port of Sape (December 19-24, 2011), and Combusting the Office of Bima District Head (January 26, 2012) were some evidences of "irrefutable" tactics application (mode of intervention) in a disruptive mass protest conducted by a group of citizens who called themselves "Front Rakyat Anti Tambang (FRAT) Bima" (Anti-Mining People's Front) in articulating their demands (claims-making) to the Government of Bima District during 2011-
2012. The anarchist social protest became an expression of the citizens' awareness about environmental citizenship, in which the local authority was required to really act as an actor who should ensure maximum respect and protection over citizens' environmental rights, not just put aside, erode, or even negate their chances to enjoy the benefits of their constitutional rights. Environmental issues as the "core value" of FRAT Bima's movement confirmed the fact that the issues raised by the environmental protesters basically reflected complex problems within the "modern 
development" paradigm; i.e., undesirable development patterns and unsustainable use of resources, fragility of local livelihood, environmental risks and impacts, community rights and the right to a make decisions on the use of local natural resources, development and environment injustice, and undemocratic policy process (Banpasirichote, 2004, p. 259).

FRAT Bima's claim-making applied maximally some disruptive tactics (nonconventional repertoires) in its movement, such as strikes, pickets, boycotts, riot, civil disobedience and other confrontation forms. ${ }^{1}$ However, these tactics were fundamentally driven by the local government's initiative who gave a permit of exploration of potential extractive resources (gold) in Lambu, Sape, and Langgudu SubDistricts to two mining companies through a Decree No. 188.45/357/004/2010. The Decree of the Head of Bima District No. $188.45 / 357 / 004 / 2010$ on Adjustment of Mining Business License, issued on April 28, 2010, was an adaptive regulation for the previous Mining Authority No. 621/2008 dated May 22, 2008, that authorized exploration power to two corporations namely PT Sumber Mineral Nusantara with a mining area covering 24,980 hectares and PT Mineral Indo Citra Persada with a mining area covering 14,318 hectares.

\footnotetext{
Contrast to the variants of radical social protest (which maximizes the use of non-conventional repertoires in which the element of physical violence is always attached to each act of resistance), nonviolentconventional protest tactics can be long-marchers (rallies), sit-ins, distributing information (leaflets/ pamphlets), petition, press-conferences, and so forth. As conceptualized by Barnes \& Kaase (as cited in Quaranta, 2015, p. 23), the protest is a form of political participation that may be conventional and nonconventional. Conventional political participation refers to all those acts belonging to the constitutional process of interest aggregation and representation, which are mediated by the political institutions, and which define the relationship between the political authorities and citizens within the political arena. On the other hand, unconventional political participation is a non-institutionalized direct political action, that does not aim to disrupt or threaten the stability of liberal democracies.
}

Concerning the threat of environmental degradation, without considering the great potential of local economic growth offered by the exploration activities, underlie citizens' anarchist resistance against the local government of Bima District by damaging some public facilities to ensure their demands of policy change will be seriously responded by the local authority as the object of claim (claimant) who has been accused to derelict the primacy of "the politicization of public space" in the policy formulation process that actually comes into contact with the common interest. ${ }^{2}$

The elimination of citizen participation in the public policy formulation will always produce complicated problems, because the top-down governance mechanisms whereby environmental policies are devised at the centre may also be seen as intrusive, costly and likely to generate resistance (Smith \& Pangsapa, 2008, p. 134).

Such resistance has always been a "trimmer" while an extractive policy is issued by the governments in various parts of the world, both in developed and developing countries, because a natural resource of promotion strategy is inferior and inherently more conflict-provoking than the promotion of other economic sectors (Ascher \& Mirovitskaya, 2016 , p. 151). In response to corporate and state-led extractivism, peasant, indigenous, and other rural communities have made a diverse range of political claims in defence of their landscapes and ways of life (Latta \& Wittman, 2014, p. 268).

Although, in principle, individual and community responses to natural resource

\footnotetext{
2 State's negligence and intentional depoliticization of popular issue or space by negating citizen participation in public policy formulation are termed by Tornquist, Webster \& Stokke (2009) as "depoliticization". Depoliticization becomes the main sign of elitist democratic institutions development and flawed representation of formal political institutions, which often take place in post-colonial countries (Global South), including Indonesia.
} 
extraction initiatives should be based on a fully informed assessment of the balance of economic opportunities versus the whole range of risks that the extraction would bring (Ascher \& Mirovitskaya, 2016, p. 164). However, the citizens' uprising to the initiative of resource extraction that has been recorded in the pages of history was more inclined on the basis of their concerns about the threat of environmental degradation, without caring to treat the economic growth as the positive impact of extractive activities, because citizens are well aware that environmental degradation will always be devastating: mine tailings, oil leaks, water contamination, water pollution from extraction and processing, and plague subsoil exploitation (Ascher \& Mirovitskaya, 2016, p. 162).

This paper aims to explore the intersection between public distrust in local authorities and the awareness of environmental rights as key drivers for the emergence of FRAT Bima's anarchist social protest. Incessant politicization of environmental issues by FRAT Bima which background its disagreement over the issuance of gold mining concessions for certain corporate which accused "not through a democratic process due to public disengagement" led them to do collective protests to claim the environmental rights. This statement is really consistent with the arguments of Della Porta and Diani (as cited in Quaranta, 2015, p. 3) that "social or political protest happens to express feelings of dissatisfaction towards some policies or decisions."

The exclusion of public participation, by the local authorities, in the formulation of an extractive policy has increasingly eroded its formal legitimacy in front of the public. As a result, the intersection between environmental awareness and public distrust became the onset of villagers' resistance that eventually forced the local authorities to cancel the implementation of an extractive policy. The cancellation of the policy would not want to be taken by the local authorities because the vandal (anarchist) social resistance conducted by the mass of FRAT Bima resulted in severe damage to some public facilities or government buildings and generally threatened the conducive circumstances and public order in Bima District.

Elaboration on whether the use of disruptive tactics was consciously or unconsciously planned by FRAT Bima on the basis of moral and ethical consideration also strategic objectives would not get any portion in this article; instead, the article would rather focus on the description of the resistance strategies of FRAT Bima as a continuum, namely its repertoires sequence from conventional to unconventional, which marked the intersection between public distrust and environmental citizenship as primary drivers of the emergence of its resistance movement against the government's natural resource extraction initiatives in 2011-2012. Therefore, the questions that will guide the author in finding the research data are how do FRAT Bima's repertoires sequence like? Do environmental citizenship and public distrust in local authority become the primary impetuses for its movement?

\section{Methods}

This study used a qualitative method with a case study approach. Qualitative research aims to explore the various issues and seek answers to many questions by testing a diverse range of social and individual settings (Creswell, 2007, p. 4). Through a case study, the author aims to explore the sequence of repertoires which were sequentially applied by FRAT Bima's social protest as well as to examine its linkage with environmental citizenship and public distrust, which are assumed to be major drivers of its emergence.

The subjects of this study were selected based on purposive sampling technique, by firstly determining the key informants which were targeted as sources of research 
data; i.e., those who were directly involved as participants in FRAT Bima's movement, especially some activists who pioneered the resistance and mass mobilization during ongoing movement. Much of the information in this study was mainly based on interviews with 20 informants during the five months of fieldwork research. The kind of information which was targeted from these in-depth interviews focused on the chronology, causes, modes of intervention, and the consequences of the social movement of FRAT Bima during 2011-2012.

\section{Results and Discussion \\ The Sequence of Repertoires: FRAT Bima Case}

To categorize FRAT Bima as a social movement or merely a form of crowd or riot will never cease from being a topic of debate. Differentiating the characteristics of social movements from crowd and riot on the basis of participants' rationality will never end in the firm demarcation line. ${ }^{3}$

Most scholars have concluded that the crowd is irrational and its participants are madmen, criminals, or the dregs of society. However, there are also scientists who take a different lane, like Le Bon (1960), which actually found that crowds were composed of normal individuals who, by virtue of their participation, were transformed by some unique, collective psychological processes in the crowd (as cited in McPhail 1989, p. 402). Referring to Le Bon's conception, FRAT Bima is classified by the author as a form of crowd and riot, as well as social movement.

\footnotetext{
Participants of the social movement are considered more rational in their actions, while a crowd/riot seems only be done by a crazy person, the dregs of society, or even criminals. For detail information, see Rosen, G. (1968). Madness in Society. New York: Harper; Moscovicci S. (1985). The Age of the Crowd. Cambridge: Cambridge University Press; Sighele, S. (1894). La Foule Criminelle. Paris: Alcan.
}

As a form of collective behaviour, crowds are political acts in which participants undertake violence to express grievances and attempt to spur policy change, and collective behaviour itself involves the activity of groups of individuals, localized in time and space, that possess some elementary degree of coordination between the members of the group (Turner \& Killian, 1972, pp. 4-6). It involves such activity as riots, strikes, lynching and demonstrations (Wasserman, 1978, p. 379). Intertwined with this formulation, in the form of political protest, crowd can be considered as "a means of political repress, namely the use of tactics as petitions, demonstrations, boycotts, rent or tax strikes, unofficial industrial strikes, occupations of buildings, blocking of traffic, damage to property, and personal violence" (Marsh \& Kaase, 1979, p. 59).

Coordination is a marker that crowd can also be categorized as one type of social movement (Drury, Reicher, \& Stott 2003). Based on this argument, FRAT Bima was a manifestation of the crowd and an environmental issue based social movement (the environmental movement) which was attached to the ritual of coordination and mobilization in its processes. This is consistent with the argument of Tilly (1994, p. 7), which said that environmental movements often involve specific communities mobilizing and coordinating their activities against an environmental hazard or planned development. They present a sustained challenge to power holders and state bodies through feisty demonstrations of "commitment, unity and worthiness."

Some authors have argued that the ability of social movements to bring about political change at various levels depends on their ability to disrupt existing practices (Fishman \& Everson 2016; Piven \& Cloward 1979) and on using a variety of tactics (Morris 1986), including violence. The official cancellation of enforcement of the Decree 
No. $188.45 / 357 / 004 / 2010$ by the District Head of Bima on January 28, 2012 (two days after subversive actions and riots happened) was a marker of FRAT Bima's ability in launching disruption to the practice of undemocratic governance, even though the disruption cannot distance itself from the violent acts.

The disruption of FRAT Bima to the local authority, which contained elements of violence in the form of public facilities destruction, increasingly asserted that it was a form of radical or anarchist environmental movement. The disruptive tactics applied by FRAT Bima increasingly emphasized the characteristics of its movement as a radical movement that carried the issue of environmental saving. This fact reflects the truth of the thesis of Banpasirichote (2004, p. 235), which says that the characteristics of radical movements are largely appraised in terms of the types of activities they have undertaken. In the eyes of both the general public and government, radical actions include destroying and trespassing government property and buildings, roadblocks, burning of politicians' effigies, performing cursing rituals, and camping out in front of government buildings; also, there were situations where the protests ended up in violent confrontations with the police. These types of action are regarded as too threatening for the authorities because the general public is still not used to such actions.

As shown by the anarchist resistance of FRAT Bima, the radical environmental movement could not be separated from three common characteristics (a) an uncompromising position, (b) direct action versus lobbying, and (c) a grass-roots, non-hierarchical structure (Eagan as cited in Trujillo, 2005, p. 146). Social movements generate influence by using extrainstitutional tactics-tactics that are subversive and disruptive in nature - to challenge authority and broadcast grievances from the margins of society (Gamson 1990; King \& Soule 2007; McAdam 1982; Piven \& Cloward 1977).
These extra-institutional tactics are thought to be influential primarily by their ability to disrupt the resources and routines of their target organizations. Disruption pressures a target to pay attention to activists' claims and potentially forces targets to concede to their demands (King, 2011, p. 491). And last but not least, subversive modes of intervention such as strikes, boycotts, social ostracism, fasts, sabotage, blockades - these put pressure on opponents, without necessarily persuading them (Johansen \& Martin, 2008, p. 507).

Referring to the resistance of FRAT Bima which lasted from 2011 to 2012, various forms of action or mode of intervention have been implemented to articulate its demands to the local authority in the form of petitions, marches, demonstrations, occupations of public facilities, confrontation with the police, and even destruction (burning) government buildings. Such extra-institutional tactics have become a means of suppressing the local government to seriously take responsive action to the demands of FRAT Bima who required an extractive policy cancellation that they feared would have a negative impact on the quality of agricultural land as the main source of livelihood of the villagers.

The precursor to the formation of the FRAT Bima was originated from the initiative of a number of students who organized themselves as Kesatuan Mahasiswa Lambu Bima (KMLB) "Union of Lambu-Bima's Students". This group of students who first expressed the refusal attitude to the local government's agenda of mining operations development in the sub-districts of Sape, Langgudu, and Lambu. To garner support and public awareness about the mining issue which they challenged, KMLB disseminated information to the general public in three sub-districts through various media such as pamphlets and limited round-table discussions. In tune with the increasing number of people (subjects) who have the same vision with them, particularly those from farmers and 
rural youths, FRAT Bima was then formed on the basis of their mutual agreement.

After being formed, FRAT Bima began its social activism by publicly delivering propaganda about the negative impact of mining activities through a documentary film which obtained from JATAM (Jaringan Advokasi Tambang) "Network of Mining Advocacy". This propaganda was very effective in changing public perceptions so that they were encouraged to participate in all actions of FRAT Bima.

\section{Picture 1.}

The Mass of FRAT Bima

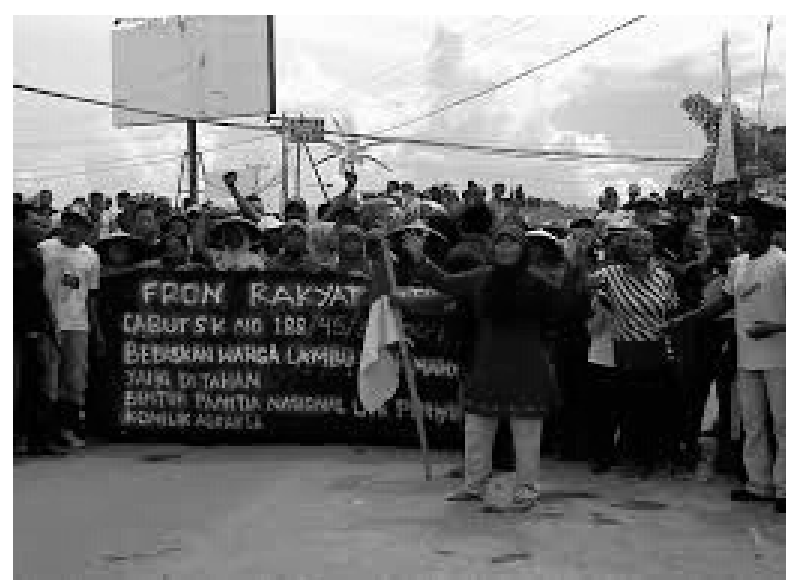

Source: berdikarionline.com

On January 8, 2011, FRAT Bima did its first action in the form of convoy around some villages in Lambu and Sape SubDistricts to publicly disseminate about the local government's extractive policy to gain support from villagers through a Petition of Mining Policy Rejection. The second action was held on January 31, 2011, in the form of a lawful demonstration in front of the Office of Lambu Sub-District Head while carrying certain physical proofs which they took from the mining site such as cables, diggers, and chemical liquids to be shown to the government officials of Lambu Sub-District to justify the truth of mining operations in their villages. These physical shreds of evidence were provided beforehand to answer the pretext of apparatus that "mining operations have not been performed in the Lambu Sub-District areas." The Head of Lambu Sub-District was required by FRAT Bima to declare his opposition to the Decree No. 188.45/357/004/2010 and also required the presence of the Head of Bima District to directly discuss with the mass of FRAT Bima in the third encounter that would take place on February 10, 2011. Then, the Head of Lambu Sub-District agreed to accommodate the demonstrators' demands to sign a refusal statement of mining policy and promised to bring the Head of Bima District on the next planned meeting.

Knowing about the absence of Bima District's Head at the Office of Lambu SubDistrict Head in their third demonstration on February 10, 2011, which included about 7,000 participants, the atmosphere of demonstration began with the masses suddenly tearing down the gates of the office of Lambu Sub-District. Local police officers responded firing tear gas, rubber bullets, and even real bullets. Due to this, there was a number of participants who became victims. The mass of FRAT Bima increasingly wreaked their frustration by burning several cars and buildings including the main facilities of Lambu Sub-District's Office.

\section{Picture 2.}

The Protesters Burnt the Office of the Head of Lambu Sub-District on February 10, 2011

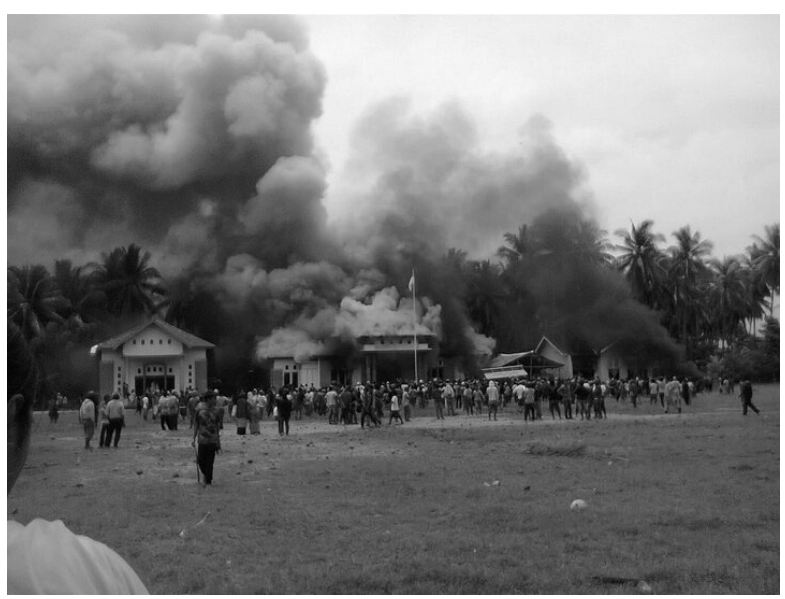

Source: berdikarionline.com 
As a consequence of this brutal action, some demonstrators were arrested by the police. This arrest consequently triggered a sympathetic reaction of society to FRAT Bima. Communities then went to the Office of Legislature, urged the legislators to initiate the revocation of the District Head's Decree No. 188.45/357/004/2010 and asked for the police to release some protesters who have been named suspects.

Due to no satisfied responses from the local authorities (executive, legislative and police), concerning the revocation of mining policy and the release of demonstrators who were jailed for several months after the anarchist third action in front of the Office of Lambu Sub-District Head, crowds of FRAT Bima began to explore the application of port forced occupation strategy. This port forced occupation lasted four days (December 1924,2011 ) and ended in dispute as a result of police repression, in which four protesters died from gunshot wounds and 20 others were arrested. Responding to a crackdown by the police, the mass of the FRAT Bima then damaged a number of public facilities that existed within and outside the port. A number of village government's offices, buildings of governmental agencies, and the sub-district sector police headquarter became the victims of this massive fury.

Picture 3.

The Protesters Occupied Forcefully the Port of Sape on December 19-24, 2011

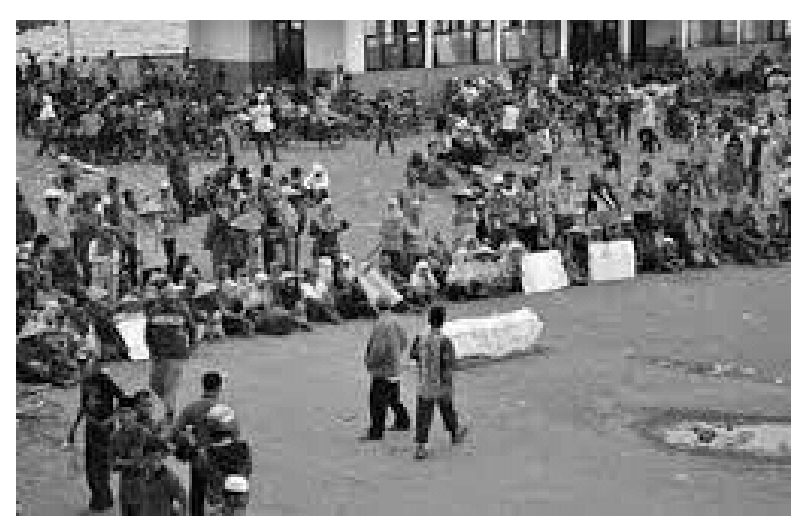

Source: mr-lambu.blogspot.com
On January 26, 2012 a thousand of FRAT Bima's supporters conducted a massive demonstration in front of the Office of Bima District Head to articulate similar demands for the cancellation of the Decree No. 188.45/357/004/2010 and the release of dozens of citizens who had been detained in jail on charges of vandalism (anarchism) for two radical actions (February 10, 2011 and December 19 to 24, 2011). In this massive demonstration, the mass of FRAT Bima also performed the forced occupation of the Office of Bima District Head as they did on December 14 to 242011 in the port of Sape.

The unclear attitude of the Head of Bima District to all demands of FRAT Bima, particularly his reluctance to revoke the decree No. 188.45/357/004/2010, resulted again in a chaotic demonstration at that time. Not getting a satisfied response from the local authorities, the mass of FRAT Bima then ripped and burned the Office of Bima District Head. Despite the ongoing chaos, there were no repressive actions from the police officers. Because of this vandalism, the Office of Bima District Head along with its existing work facilities were destroyed and burnt by the masses. A number of official cars around the area were also devastated.

\section{Picture 4.}

The Protesters Combusted the Office of the Head of Bima District on January 26, 2012

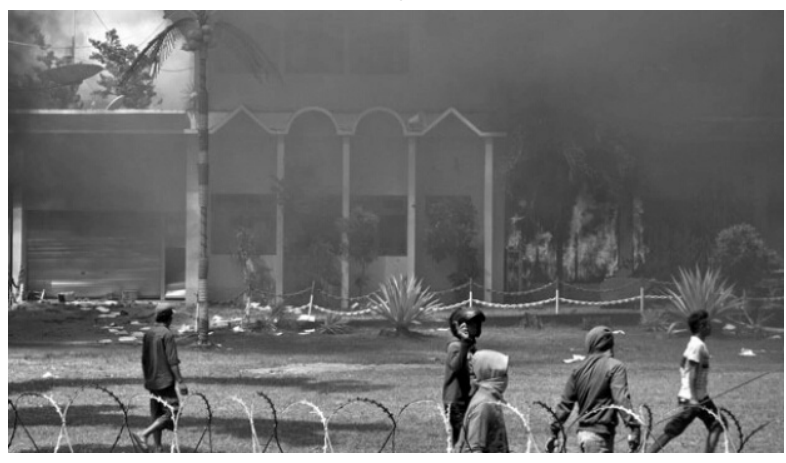

Source: nasional.tempo.co 
Recognizing the increasingly widespread escalation of conflict as a form of public resistance against the issued mining policy and to restore conducive situations in the district of Bima, two days after the riots of forced occupation were undertaken by the masses of FRAT Bima, District Head officially revoked decree No. 188.45/357/004/2010. This revocation decision was based on the Recommendation Letters from the General Directorate of Mineral and Coal, Ministry of Energy and Mineral Resources of the Republic of Indonesia and the Decree of the Legislature's Chairman in 2012.

The series mode of intervention of FRAT Bima during the 2011-2012 period has justified the validity of the thesis that "one of main elements of political protest is that the actions forming its repertoire can be considered hierarchically ordered" (Van Deth 1986; Kaase, 1989 as cited in Quaranta, 2015, p. 24). In other words, forms of action in the political protest can be distinguished according to the "logic," or modus operandi, which the activists assign them (Della Porta \& Diani, 2006, p. 171). This hierarchic repertoire order consists of four fundamental thresholds. The first threshold indicates the transition from conventional to unconventional politics. Signing petitions and participating in lawful demonstrations are unorthodox political activities but still within the bounds of accepted democratic norms. The second threshold represents the shift to direct action techniques, such as boycotts. The third level of political activities involves illegal, but nonviolent acts. Unofficial strikes or a peaceful occupation of a building typify this step. Finally, a fourth threshold includes violent activities such as personal injury or physical damage (Dalton, 1988, p. 65).

As a summary, the following table presents the sequence of repertoires, from the conventional to the unconventional ones, which were used by FRAT Bima as the chosen ways to articulate the certain environmental issue and their political aspirations which were background by the presence of the Decree of Bima District Head No. 188.45/357/004/2010.

Those sequential steps, as done by FRAT Bima, show that political protest is a continuum. It means that political protest can be seen as a sequence of "steps" of increasing its intensity or its forms of action, from legal conventional repertoires such as voting or campaigning to unconventional activities such as demonstrations, boycotts or occupations of buildings. According to this framework, the concept of political protest can be measured using five indicators: signing a petition or attending lawful and peaceful demonstrations, joining in boycotts, joining unofficial strikes, occupying buildings or factories, and damaging physical facilities.

Table 1.

Sequence repertoires and/or Chronology of Claim-Making of FRAT Bima in 2011-2012

\begin{tabular}{|c|c|c|}
\hline No. & Date & Forms of Action \\
\hline 1 & January 8, 2011 & $\begin{array}{l}\text { a. Convoying around some villages in Lambu and Sape Sub-Districts to publicly } \\
\text { disseminate the local government's extractive policy. } \\
\text { b. Rallying the support of villagers through a Petition of the Mining Policy Rejection. } \\
\text { c. First lawful demonstration at the Office of Lambu Sub-District Head. }\end{array}$ \\
\hline 2 & January 31, 2011 & Second lawful demonstration at the Office of Lambu Sub-District Head. \\
\hline 3 & February 10, 2011 & Burning the Office of Lambu Sub-District Head and other public facilities. \\
\hline 4 & December 19-24, 2011 & Occupying a fundamental public building (Port). \\
\hline 5 & January 26, 2012 & $\begin{array}{l}\text { a. Burning the Office of Bima District Head and the other public facilities. } \\
\text { b. Damaging other public buildings. } \\
\text { c. Freeing certain prisoners from jail. }\end{array}$ \\
\hline
\end{tabular}

Source: Primary Data Obtained from In-depth Interviews, March 2018 
Environmental Citizenship and Public Distrust in the Local Authority as primary impetuses of FRAT Bima's Radical Resistance

Studies on social protests, both violent and non-violent, viewed from the motivating factors (impetuses), strategies, outcomes (success/failure), or even how the state deals with it, have been done by a lot of scholars such as Tabib (2016); Steinhardt \& Wu (2016); Enos, Kaufman, \& Sands (2017); and Shah (2017). Not moving away from these aspects, this paper will elaborate the context of the special social protest (FRAT Bima) based on the dimensions of repertoire and the reason for its emergence attached to the concept of public distrust and environmental citizenship.

The Decree of the Head of Bima District No. $188.45 / 357 / 004 / 2010$ becomes the basic point of departure to explain the dynamics of anarchist social protest of FRAT Bima during 2011-2012. The applied sequence of repertoires in the protest of FRAT Bima was oriented by the participants to oppose the extractive policies of Bima District Head which seemed unpopular and contradictory to the fundamental interests of the subjects who inhabit the area of policy implementation (residents of Lambu, Sape and Langgudu Sub-Districts). Theoretically, this sequence of repertoires reflects the four categories of approach or forms of action which are prevalent in social protests, as conceptualized by Tarrow (as cited in O'Brien, 2016, p. 15), namely Appeal - present, address; Demonstrational - gather, display, march, perform, costume, replant; Confrontational - disrupt, chant, enter, obstruct, occupy; and Violent - damage.

The application of modes of intervention in the FRAT Bima's social protest, from Appeal to Violent ones, actually indicates that the relationship between the state and civil society was highly adversarial. This adversarial power relations was justified by the emergence of people's resistance (FRAT Bima) against the specific public policy as a product of local government's technocratic formulation process (the Decree of Bima District Head No. 188.45/357/004/2010) that also overlapped with the inability of the local authorities to deal with the matter, especially by underestimating the potential for conflict inherent in the proposed mining policy cancellation.

The inability of the local government to sustain itself with democratic characteristics such as openness and respect for deliberation in the formulation of mining policy has caused it to be infected by the "vulnerability virus" of delegitimation from social movement actors such as FRAT Bima. In other words, the Government of Bima District was unable to avoid being a target of disruptive massive protest tactics due to its negligence to maximize the institutional capacities (in the form of repression, facilitation and routinization) as intended by Walker, Martin \& McCarthy (2008). Its immunity to the disruption of social movement organization was devastated due to its lack of abilities to reduce the chance of transformation of protest tactics, from conventional to radical ones. According to them, the anarchist social protest that occurred in Bima in 2011-2012 ago was really contradictory with the theses of Walker, Martin and McCarthy, in which the local authorities seemed to be "barren" to take full advantage of their institutional capacity in response to FRAT Bima's demands. As a result, anarchist protest tactics are inevitably utilized by a group of opponents of government policy as an effective means of accelerating the realization of their desired policy changes.

The Decree of Bima District Head No. $188.45 / 357 / 004 / 2010$ was seen by its opponents would only lead to adverse effects for the environment. Society's refusal swelled when the mining company (PT Sumber Mineral Nusantara) conducted exploration activities at particular spots, namely agricultural land and protected areas, in the Langgudu, Sape, and Lambu Sub-Districts, which would cause inconvenience and disruption to the local 
community who has dominant subsistence (livelihood) as onion farmers.

“...The Decree of Bima District Head No. 188.45/357/004/2010 required ten thousand hectares of farmland and protected forest areas in the Sub-Districts of Lambu, Sape, and Langgudu as gold mining operation site for the PT Sumber Mineral Nusantara and PT Mineral Indo Citra Persada. We believed that this extractive resource exploration would only bring misery, especially for farmers in all villages in three subdistricts. Forests and agricultural lands would be converted into mining areas. This kind of action would shrink the water supply for agricultural irrigation. The anxiety over the threat of environmental degradation and the survival of the peasants' lives has led to citizen resistance to non-populist powerholders' policies..." [Interview with Hasanuddin, Chairman of FRAT Bima, on March 7, 2018]. ${ }^{4}$

This statement clearly shows that the impetus of FRAT Bima's resistance movement really intersects with environmental citizenship, which is the citizenship domain which focuses on contractual rights and entitlements within the public sphere and entails the extension of rights-based discourse to cover environmental rights. According to this concept, citizens have constitutional space to freely give their consent to the state to define environmental rights in their interest (Dobson, as cited in Humphreys, 2009, pp. 171-172). Citizens are entitled to publicly express their rejection against any development initiatives set by the government if they are deemed to only aggravate the quality

\footnotetext{
4 Similar arguments also come from other activists who intensively involved in all FRAT Bima's Protests during 2010-2012 such as Adi Cuswardana, Abdul Rahman, Anas, Muliadin, and Adi Supriadi. They were interviewed interchangeably by the author in March 2018.
}

of life of the people. Based on this elaboration, citizenship as a right is not only limited to civil, political and social (as well as economic) rights, but also can take on other broader forms such as the right to the quality of the environment and its protection from degradation, the latter popularly known as environmental citizenship (Stokke, 2017, pp. 28-29).

Within the framework of the struggle of FRAT Bima, the concept of sustainable development that emphasizes "the hand-inhand fulfilment between human development goals and environmental conservation" is required to be the basis of consideration of the local authorities before the mining initiatives are formulated. This demand can also be positioned as a marker that environmental citizenship became the impetus of FRAT Bima's protest. Environmental citizenship offers a "conceptual convergence of the perspective of sustainable development and the perspective of rights, duties and citizenship" (Jelin, 2000, p. 47). In addition to closely being related to the concept of environmental citizenship, citizens' rights to environmental quality and protection from degradation, as evidenced in the content of the demands which were articulated to the local authorities (revocation of the Decree of Bima District Head No. 188.45/357/004/2010), the resistance movement of FRAT Bima was increasingly manifest when the decree was concluded not through the democratic process due to citizens disengagement in its formulation.

Since the Decree of the Bima District Head No. 188.45/357/004/2010 was not an internal-oriented policy type (which has the binding force of apparatus in the local government organizations), but the type of policy dealing with public interests, the demands of FRAT Bima that also focused on the process of decree drafting should remain public interest as its guidance, has clear and precise aims, and must be done transparently through citizen involvement. 
The absence of citizens which were involved in the drafting process of the Mining Business License, as concluded by the activists of FRAT Bima, became the accompanying factor of claims to the environmental citizenship which they were articulating to the local authorities. The depoliticization of public spaces by the Government of Bima District in the form of eliminating the participation of citizens in the discussion of public issues ultimately triggered a wave of massive public resistance because the resulting policy product was defective, non-democratic, or had poor legitimacy.

The protest of FRAT Bima to the local authority rose to the surface due to the jammed political communications between the government and the community. The offer of economic growth through the exploration efforts of natural resources that Bima District Government inadvertently contrasted with the establishment of a society that believes that mining will only bring an adverse impact on their lives. The mismatch of the local authority agenda with the collective needs of the people, especially the peasants, who inhabited the areas of Sape, Langgudu and Lambu sub-districts became the cause of the emergence of public resistance as practised by FRAT Bima. The protest became the vehicle for the expression of popular discontent over the government's unilateral actions, and it was a form of asymmetrical political communication to elevate their agendas in the public consciousness (McCombs and Shaw 1972; Sears and McConahay 1973; Lee 2002; Iyengar and Kinder 1987; Andrews and Edwards 2004).

Due to the Decree of Bima District Head No. 188.45/357/004/2010 concerned with the public interest, it is appropriate if citizens are involved in its formulation. Not taking this path, the Government of Bima District instead negate the space of public participation intentionally. This kind of non-democratic decision-making character that we challenged over (interview with Adi Supriadi, an activist of FRAT Bima, March 12, 2018).

The social protest of FRAT Bima was a form of public distrust in the local government leaders' commitment to the public interest. Similar to the argument of Li (2011, pp. 295296), activists of FRAT Bima really believed that local government leaders had: (1) put their own interests before the interests of the farmers; (2) did not care whether farmers would agree when they made policies; and (3) cared primarily about the powerful and rich persons' needs, and neglected the interests of ordinary people (farmers).

If we refer to Piotr Sztompka's argument (as cited in Hosking, 2013, p. 3-4), the context of the FRAT Bima's social protest reflects the public outcry as well as their unbelief at the actions of the local authorities. The low level of openness and accountability of the local authority ultimately forces the public to stage an act of resistance through the use of various non-violent and violent repertoires of contention. Thus, the anarchist social protest of FRAT Bima was a public corrective endeavour towards the decline of the formal legitimacy of the Government of Bima District.

The strengthening of public distrust in the local authorities which drove the emergence of the anarchist resistance movement of FRAT Bima was based on the acute "institutional" weakness of the local government in facilitating and accommodating the public demands. The absence of community involvement in the formulation of mining policy, plus the lack of intensive dissemination of information (socialization) by the local government over the mining policy further undermined the degree of its legitimacy in the eyes of the public. On the basis of that, it is quite natural that most citizens doubt the "sincere" orientation of the local authorities which seek to increase the degree of regional economic growth through the extraction of potential available 
natural resources. The restriction of public deliberation in such policy formulation led to the negative perception that the extractive policy was completely inappropriate because it really contrasted with the collective needs of the people who lived in Sape, Langgudu and Lambu Sub-Districts.

The combination of awareness of environmental rights (environmental citizenship) with public distrust in the local authority became the primary impetuses of the resistance movement of FRAT Bima during 2011-2012. The asymmetric political communications between state and society which was inherent in this extractive policy issue have led to the creation of an adversarial relationship between them. The public was not willing to cooperate with local authorities in the implementation of policies that were viewed not through a democratic process and contained a "vague" orientation, because the authorities took the opposite direction with their fundamental interests.

\section{Conclusion}

The context of anarchist social protests which occurred in Bima District during 20112012 reflects "the result of an undemocratic environmental policy-making process, as conducted by the local government, would be sometimes resisted by a certain local community even through violent ways." The lack of formal legitimacy of the local authorities, which was supported by the growing awareness of public environmental citizenship, has led the sequential application of both conventional and non-conventional strategies in the articulation of the public demands.

The FRAT Bima's resistance has added the historical notes about how the villagers' movements are conducted to clarify a number of aspects of citizenship, especially the right to environment and political participation, to the local governments. To overcome the perceived environmental and political injustices, this social protest has applied vandalism (anarchism) in the form of destruction and even the burning of public facilities as a chosen strategy to pressure the local governments to act responsively and accommodate their demands.

The sequence of repertoires (from Appeal to Violent) in FRAT Bima's social protest occurred due to the low-level of the government's responsiveness in accommodating the public claims about the cancellation of an undemocratic environmental policy. The awareness of environmental citizenship, which was overwhelmed by the problem of delegitimation of the local authority, became the two main drivers of the emergence of such an anarchist social protest.

In other words, in addition to being closely related to citizens' awareness of environmental citizenship, the occurrence of anarchist social protests was triggered by the low "formal legitimacy" of the local governments as the seed of public distrust in the intentions (orientations) of environmental governance policies that would be enforced by turning farmland into a mining location.

\section{References}

Andrews, K. T. \& Edwards, B. (2004). Advocacy organizations in the U.S. political process. Annual Review of Sociology, 30, 479-506.

Ascher, W. \& Mirovitskaya, N. (2016). Development strategies and inter-group violence: Insights on conflict-sensitive development. New York: Palgrave Macmillan.

Banpasirichote, C. (2004). Civil society discourse and the future of the radical environmental movement in Thailand. In Guan, L. H. (Ed.), Civil Society in Southeast Asia (pp. 234-264). Singapore: ISEAS Publications.

Bupati Bima. (2010). Surat keputusan Bupati Bima No. 188.45/357/004/2010. Bima: Bupati Bima.

Creswell, J. W. (2007). Qualitative inquiry and research design: Choosing among five 
approaches. (2nd ed). Thousand Oaks: Sage Publications.

Dalton, R. J. (1988). Citizen politics in western democracies: Public opinion and political parties in the United States, Great Britain, West Germany, and France. Chatham: Chatham House.

Della Porta, D. \& Diani, M. (2006). Social movements: An introduction. Oxford: Blackwell.

Drury, J., Reicher, S., \& Stott, C. (2003). Transforming the boundaries of collective identity: From the "local" antiroad campaign to "global" resistance?. Social Movement Studies, 2, 191-212. doi: 10.1080/147-4283032000139779.

Enos, R. D., Kaufman, A. R. \& Sands, M. L. (2017). Can violent protest change local policy support: Evidence from the aftermath of the 1992 Los Angeles riot. Research Report Department of Government. Harvard: Harvard University.

Fishman, R. M. \& Everson, D. W. (2016). Mechanisms of social movement success: Conversation, displacement and disruption. Revista Internacional de Sociología, 74(4). doi: 10.3989/ris.2016.74.4.045.

Gamson, W. A. (1990). The strategy of social protest. Belmont, CA: Wadsworth.

Hosking, G. (2013). Trust and distrust in the ussr: An overview. The Slavonic and East European Review, 91(1), 1-25.

Humphreys, D. (2009). Environmental and ecological citizenship in civil society. The International Spectator, 44(1), 171-183.

Iyengar, S. \& Kinder, D. R. (1987). News that matters: Television and American opinion. Chicago: University of Chicago Press.

Jelin, E. (2000). Towards global environmental citizenship. Citizenship Studies, 4(1), 47-63.

Johansen, B. \& Martin, B. (2008). Sending the protest message. Quarterly Journal of the Gandhi Peace Foundation, 29(4), 503-520.

Kaase, M. (1989). Appendix C. The cumulativeness and dimensionality of the participation scales. In Jennings, K. M., van Deth J. W. (Eds.), Continuities in Political Action: A Longitudinal Study of Orientations in Three Western Democracies (pp. 393-396). New York: Walter de Gruiter.

King, B. G. (2011). The tactical disruptiveness of social movements: Sources of market and mediated disruption in corporate boycotts. Social Problems, 58(4), 491-517.

King, B. G. \& Soule, S. A. (2007). Social movements as extra-institutional entrepreneurs: The effect of protest on stock price returns. Administrative Science Quarterly, 52, 413-42.

Latta, A. \& Wittman, H. (2014). Ecological citizenship in Latin America. In E. F. Isin \& P. Nyers. (Eds.), Routledge Handbook of Global Citizenship Studies (pp. 265-273). New York: Routledge.

Le Bon, G. (1960). Psychologie des foules. (G. Le Bon, Trans.). New York: Viking Press.

Lee, T. (2002). Mobilizing public opinion: Black insurgency and racial attitudes in the civil rights era. Chicago: University of Chicago Press.

Li, L. (2011). Distrust in government leaders, demand for leadership change, and preference for popular elections in rural china. Political Behavior, 33(2), 291-311.

Marsh, A. \& Kaase, M. (1979). Political action: A theoretical perspective. In S. H. Barnes, M. Kaase. (Eds.), Political Action: Mass Participation in Five Western Democracies (pp. 27-56). Beverly Hills, CA: Sage.

McAdam, D. (1982). Political process and the development of black insurgency, 1930-1970. Chicago: University of Chicago Press.

McCombs, M. E. \& Shaw, D. L. (1972). The agenda-setting function of mass media. The Public Opinion Quarterly, 36(2), 176-187.

McPhail, C. (1989). Blumer's theory of collective behavior: The development of a nonsymbolic interaction explanation. The Sociological Quarterly, 30(3), 401-423. 
Morris, A. D. (1986). Origins of the civil rights movements. New York: The Free Press.

Moscovicci S. (1985). The age of the crowd. Cambridge: Cambridge University Press.

O'Brien, T. (2016). Camping, climbing trees and marching to parliament: Spatial dimensions of environmental protest in New Zealand. Kōtuitui: New Zealand Journal of Social Sciences Online, 11(1), 1122. doi: 10.1080/1177083X.2015.1012170.

Piven, F. F. \& Cloward, R. A. (1977, 1979). Poor people's movements: Why they succeed, how they fail. New York: Vintage Books.

Quaranta, M. (2015). Political protest in Western Europe: Exploring the role of context in political action. London: Springer.

Rosen, G. (1968). Madness in society. New York: Harper.

Sears, D. O., \& McConahay, J. B. (1973). The politics of violence: The new urban blacks and the Watts riot. Boston: Houghton-Mifflin.

Shah, K. M. (2017). Dealing with violent civil protests in India. issue briefs and special reports. New Delhi: Observer Research Foundation.

Sighele, S. (1894). La foule criminelle. Paris: Alcan.

Smith, M. J. \& Pangsapa, P. (2008). Environment and citizenship: Integrating justice, responsibility, and civic engagement. New York: Zed Books Ltd.

Steinhardt, H. C. \& Wu, F. (2016). In the name of the public: Environmental protest and the changing landscape of popular contention in China. The China Journal, 75, 61-82.

Stokke, K. (2017). Politics of citizenship: Towards an analytical framework. In
Stokke, K. \& Hiariej, E. (Eds.), Politics of Citizenship in Indonesia (pp. 23-53). Jakarta: Yayasan Pustaka Obor Indonesia. Tabib, R. (2016). Mobilized publics in postqadhafi libya: The emergence of new modes of popular protest in Tripoli and Ubari, Mediterranean Politics, 21(1), 86106.

Tilly, C. (1994). Social movements as historically specific clusters of political performances. Berkeley Journal of Sociology, 38, 1-30.

Tornquist, O., Webster, N. \& Stokke, K. (2009). Rethinking popular representation. Houndmills: Palgrave Macmillan.

Trujillo, H.R.(2005). The radicalenvironmentalist movement. In B. A. Jackson, J. C. Baker, K. Cragin, J. Parachini, H. R. Trujillo, \& P. Chalk. (Eds.), Aptitude for Destruction: Case Studies of Organizational Learning in Five Terrorist Groups (pp. 141-175). California: RAND Corporation.

Turner, R. H. \& Killian, L. M. (1972). Collective behavior. (2nd ed). Englewood Cliffs, N.J. : Prentice-Hall.

Van Deth, J. W. (1986). A note on measuring political participation in comparative research. Qual Quant, 20(2), 261-272.

Walker, E. T., Martin, A. W., \& McCarthy, J. D. (2008). Confronting the state, the corporation, and the academy: The influence of institutional targets on social movement repertoires. American Journal of Sociology, 114(1), 35-76.

Wasserman, I. M. (1978). State policy outputs and collective behavior: A causal reinterpretation. Social Science Quarterly, 59(2), 379-385. 